\title{
SATELLITE STUDIES OF FRESH-WATER IGE MOVEMENT ON LAKE ERIE
}

\author{
By Donald R. Wiesnet \\ (NOAA/National Environmental Satellite Service, Washington, D.C. 20233, U.S.A.)
}

Abstract. Since the winter of $1972-73$, NOAA visible and thermal images of North America have been available for the study of ice on the Great Lakes. The shallowest of the Great Lakes is Lake Erie, on which ice occurs from December usually through April. The NOAA series of polar-orbiting satellites collect two thermal and one visible image per day; the Geostationary Observational Environmental Satellites (GOES) collect visible and infrared images every $30 \mathrm{~min}$. NASA's Landsat satellite has an $18 \mathrm{~d}$ revisit cycle (a $9 \mathrm{~d}$ cycle when two are operating), with superb ground resolution $(79 \mathrm{~m})$. Satellite images from all three satellites were used in this study.

Ice formation, movement, and break-up in Lake Erie are different in each sub-basin, Western, Central, and Eastern, owing to the variation in depth of water, geomorphology, and meteorologic factors.

Ice movement after initial break-up in $1974-77$ resulted in the accumulation of ice at the entrance of the Niagara River at the eastern end of the lake. In 1973, satellite images show the unusual development of an ice dam across the entire width of Lake Erie and the "ice plug" at the mouth of the Niagara did not form.

The effect of wind direction on break-up patterns is seen to be critical to any attempt at forecasting date of complete ice melt as well as day-to-day distribution of ice. Satellite observation of ice in Lake Erie-and in all large lakes-provides information regularly, routinely, and synoptically from a point in space. These data are useful for the study of ice formation, movement, and break-up, and they provide an unrivaled and unprecedented data set of historical records.

RÉsumé. Études par satellite du mouvement de la glace de l'eau douce dans le lac Érié. Depuis l'hiver 1972-73, NOAA a donné dans le visible et dans le thermique des images de l'Amérique du Nord, utilisables pour l'étude de la glace dans les Grands Lacs. Le moins profond des Grands Lacs est le lac Érié sur lequel la glace dure de décembre jusque, d'habitude, avril. Les séries NOAA de satellites à orbites polaires réunissent quotidiennement deux images dans le thermique et une dans le visible. Les Satellites Géostationnaires d'Observation de l'Environnement (GOES) donnent des images dans le visible et dans l'infra-rouge toutes les 30 minutes. Le satellite Landsat de la NASA a une période de retour de 18 jours (une période de 9 jours lorsqu'il y a deux satellites en usage simultané) avec une excellente résolution au sol (79 $\mathrm{m})$. Les images de ces trois types de satellites ont toutes les trois été utilisées dans cette étude.

La formation de la glace, son mouvement et sa débâcle dans le lac Érié sont différents dans chaque sous-bassin, l'Occidental, le Central et l'Oriental en raison de la variation dans la profondeur de l'eau, la géomorphologie et les facteurs météorologiques.

Le mouvement de la glace après la débâcle initiale en 1974-77 a provoqué l'accumulation de la glace à l'entrée de la Niagara River à l'extrémité Est du lac. En r 973 les images de satellites montrent le développement inhabituel d'un barrage de glace à travers toute la largeur du lac Érié et le "bouchon de glace" en tête du Niagara ne s'est pas formé.

Les effets de la direction du vent sur les phénomènes de débâcle sont considérés comme critiques jusqu'à un certain point pour la prévision de la date de l'achèvement de la fusion et de la distribution au jour le jour de la glace. Les observations par satellite de la glace dans le lac Érié et dans tous les grands lacs, procurent des informations régulières, routinières et synoptiques depuis un point de l'espace. Ces résultats sont utiles pour l'étude de la formation de la glace, de son mouvement, de sa débâcle et ils procurent une masse sans équivalent et sans précédent de données enregistrées et datées.

Zusammenfassung. Satellitenstudien zur Bewegung des Süsswassereises im Erie-See. Seit dem Winter 1972-73 stehen NOAA-Satellitenbilder von Nordamerika im sichtbaren und thermalen Spektrum zum Studium des Eises in den Grossen Seen zur Verfügung. Der seichteste der Grossen Seen ist der Erie-See; er trägt gewöhnlich von Dezember bis April Eis. Die NOAA-Satelliten auf Polbahnen nehmen pro Tag zwei Thermalbilder und ein Bild im sichtbaren Spektrum auf; die geostationären Umwelt-Beobachtungssatelliten (GOES) gewinnen Bilder im sichtbaren und infraroten Spektrum alle 30 Minuten. Der Landsat-Satellit der NASA hat einen Wiederkehrzyklus von 18 Tagen (von 9 Tagen, wenn 2 Satelliten umlaufen) mit der hervorragenden Bodenauflösung von $79 \mathrm{~m}$. Satellitenbilder aller drei Quellen wurden für diese Studie herangezogen.

Bildung, Bewegung und Verfall des Eises im Erie-See sind infolge der verschiedenen Wassertiefen, Geländeformen und meteorologischen Einflüsse in jedem Teilbecken des Sees, dem westlichen, mittleren und östlichen, unterschiedlich.

Die Eisbewegung nach dem ersten Aufbrechen in den Jahren 1974-77 führte zu einem Eisstau vor der Mündung des Niagara-Flusses am östlichen See-Ende. Die Satellitenbilder des Jahres r 973 zeigen die ungewöhnliche Entwicklung eines Eisdammes über die ganze Breite des Erie-Sees; der "Eis-Pfropfen" an der Mündung des Niagara bildete sich hingegen nicht. 
Der Einfluss der Windrichtung auf das Aufbruchsmuster erweist sich als kritisch für jeden Versuch der Vorhersage des Zeitpunkts völliger Eisschmelze, ebenso aber für die Eisverteilung von Tag zu Tag. Die Satellitenbeobachtung des Eises im Erie-See - und in allen grossen Seen - liefert regelmässige, gleichartige und gleichzeitige Informationen von einem Raumpunkt. Diese Daten sind nützlich für das Studium von Bildung, Bewegung und Verfall des Eises; sie ermöglichen eine konkurrenz- und beispiellose chronologische Aufzeichnung der Verhältnisse.

\section{INTRODUCTION}

Lake Erie is the shallowest of the Great Lakes. Bathymetric charts (Fig. I) reveal that it can be subdivided into three distinct areas: the western sub-basin, which extends from the western shoreline to the islands north of Sandusky Bay; the central sub-basin, which includes the area between the islands and the Long Point-Erie axis; and lastly the eastern sub-basin, which extends from the Long Point-Erie axis to the Niagara River outlet of the lake at Buffalo. From west to east the sub-basins get progressively deeper as may be seen on Figure I.

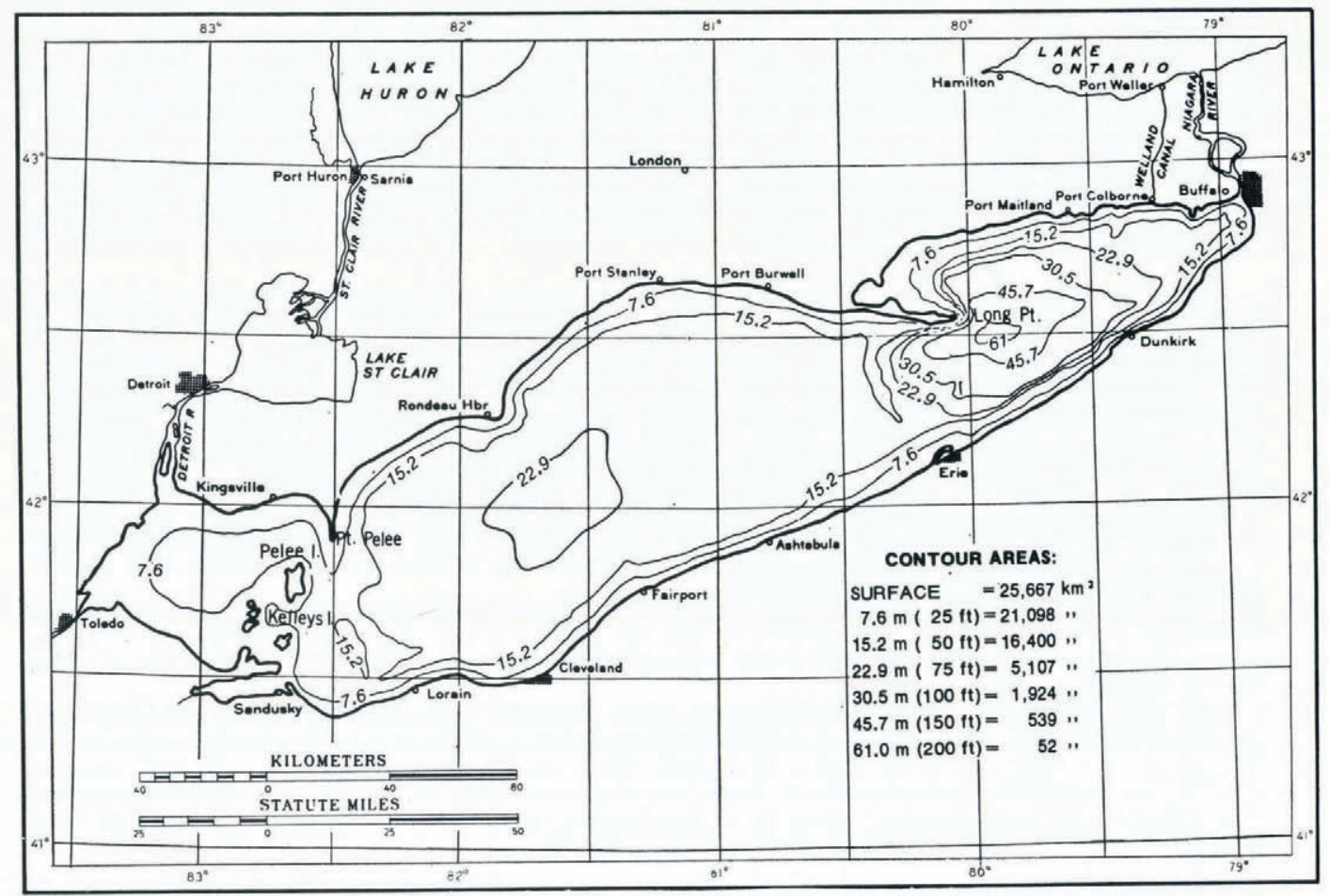

Fig. I. Bathymetric map of Lake Erie.

Ice forms in late November or early December and usually lasts until mid-April. Except for Stewart (1973), little if any work has been done on currents or thermal patterns in winter. Hutchinson ([ $\left.\left.{ }^{\mathrm{C}} \mathrm{I} 975\right]\right)$ has pointed out that orientation of the lake in relation to the prevailing westerly winds of the area favors a net transport of surface water from the north shore toward the south shore and a northerly current along the bottom. Thus, upwelling along the north shore is to be expected. Hartley ( 1968 ) found a general south-east-to-north-west circulation in the summer with bottom currents moving toward the north shore between Pelee Point and Point Aux Pins (Rondeau Harbor), easterly currents along the north shore from Point Aux 
Pins and Point Burwell, and a northerly current swinging around Long Point into Long Point Bay. Thermal studies by Irbe (r969) confirm these general patterns.

Since the winter of $1972-73$, visible- and thermal-band images of North America from NOAA satellites have been available for the study of ice on the Great Lakes. The NOAA series of polar-orbiting satellites collect two thermal images and one visible image per day with a spatial resolution of about I km; the Geostationary Observational Environmental Satellites (GOES) collect visible (day-time) and thermal (day-time and night-time) infrared images every $30 \mathrm{~min}$. NASA's polar-orbiting Landsat satellites have an $18 \mathrm{~d}$ revisit cycle (which becomes a $9 \mathrm{~d}$ cycle when two satellites are orbiting), with superb spatial resolution $(79 \mathrm{~m})$ in the visible and reflected infrared regions. Satellite images from all three satellite systems were used in this study. Prior studies of Great Lakes ice cover that utilized NOAA satellite imagery include Strong (1973), Leshkevich (1976), McMillan and Forsyth (1976), and Wartha (1977).

\section{TYPIGAL BREAK-UP PATTERN}

On Lake Erie in a typical winter, one may anticipate only one or two days of total ice cover before break-up begins. The first sign of break-up always appears in the area of Pelee Point, and extends along the east edge of Kelley's Island, Pelee Point, and the small islands at the edge of the shallow ( $7 \mathrm{~m}$ deep) western basin, usually as a result of strong northwesterly winds (Fig. 2). At about the same time, leads develop along the north shore, and the ice is compressed at right angles to the axis of the lake, resulting in ridging, thrusting, and a general pile-up of ice along the south shore. Break-up is thus initiated in the central sub-basin and in the western sub-basin by north-westerly or westerly winds. The western sub-basin ice, which is held in the sub-basin by a bottom ridge and a string of islands, does not break up at this time, although leads may develop along the north shore (Fig. 3).

The tension produced in the ice mass of the large central sub-basin causes fractures as well as ridges. When the north-west wind subsides or when the wind changes direction, and the ice is no longer under tension, floes form from the multifractured sheet. The broken ice in the central sub-basin is then free to drift and move with the current and wind. It tends to move eastward with the current toward the Niagara River (Fig. 4). The satellite images show large floes at this time, but as the ice moves eastward it becomes constricted between Long Point and Erie, Pennsylvania, where abrasion and additional fracturing occurs.

The western sub-basin, more than $60 \mathrm{~m}$ deep off Long Point, receives these floes. In Long Point Bay, however, the winds usually clear out the ice in late February (Fig. 4). The central sub-basin, then, clears systematically from west to east, while the western and eastern subbasins remain ice covered.

At the eastern extreme of the lake, thawing begins in the Toledo area, aided by industrial and municipal heated water effluents and by the water of the Detroit River, which has also been warmed by industrial and municipal effluents. Soon the ice of the western sub-basin ice is totally detached from shore and is free to be moved by the wind, usually eastward toward the lake islands (Fig. 4). But the vast bulk of lake ice is still offshore at the eastern end of the lake. Commonly, ridges will form as the ice is forced eastward and is compressed by wind and current action.

The western basin is normally free of ice in mid- or late March (Fig. 5). The average opening date for ships in western Lake Erie (Cleveland) is 24 March (Boyce, I973). In Buffalo, however, the average historical opening of the harbor to shipping is I I April, eighteen days later. We can see from Figures $3-5$ why this is so. The ice, carried by wind and current, moves toward the outlet of the lake near Buffalo. Here it remains until it melts in April, impeding lake shipping not only in Buffalo harbor but also at the exit of the Welland Canal. In 1976, the ice at Buffalo was last recorded by NOAA-4 on ig April. 


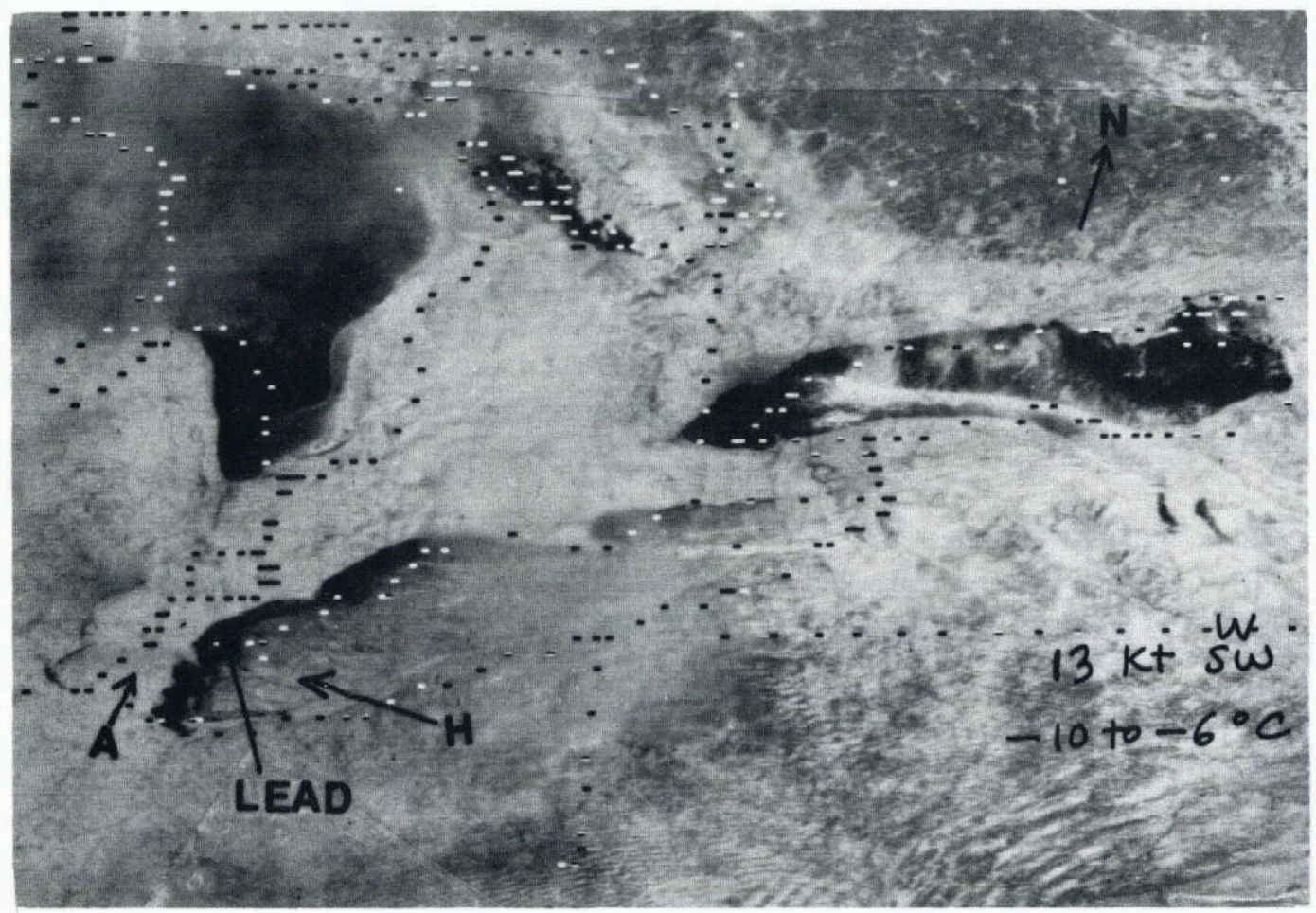

Fig. 2. GOES image 7 February $1968,16.30 Z$. A typical onset of break-up, with a lead widening east of the islands and a westerly wind. The ice in the western basin is denoted by $A$; moving ice in the central basin by $H$.

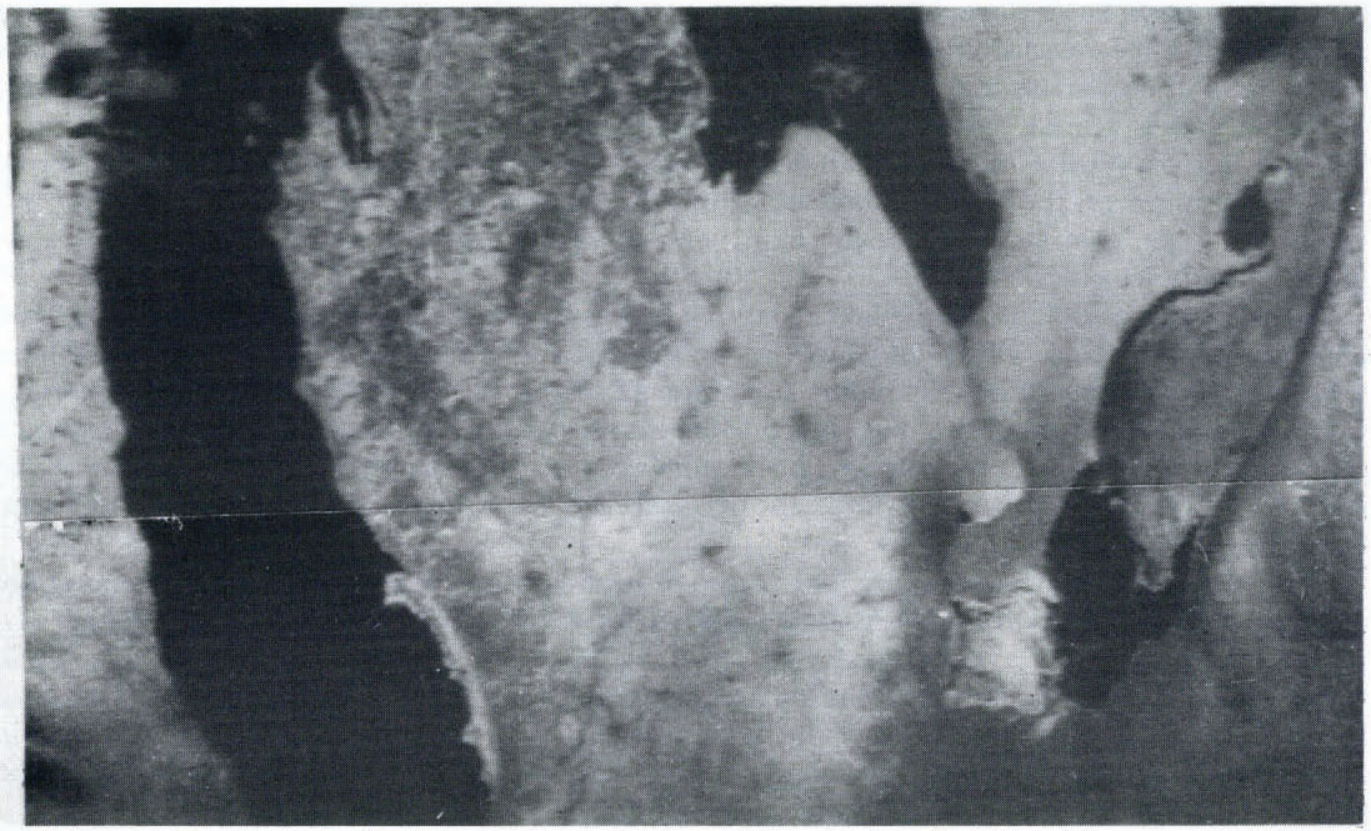

Fig. 3. NOAA-4 VHRR (visible), ${ }_{4} 4$ February 1976, 15.00 Z. Note the ice-free areas. Note the clearing of the western portion of the central sub-basin and the leads developing along the north and west shores of the western sub-basin. 


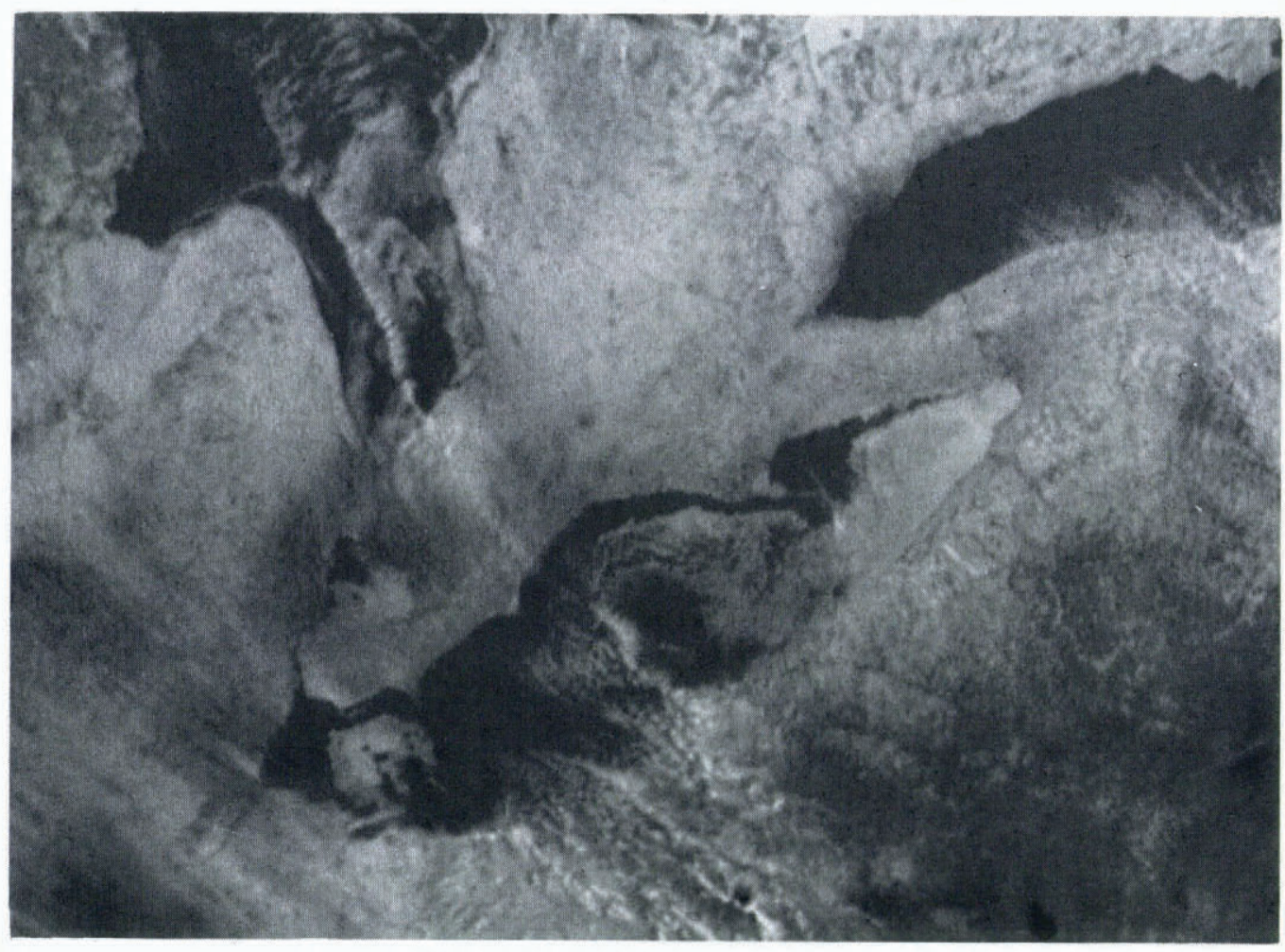

Fig. 4. NOAA-4 VHRR (visible), 23 February 1976, 15.0o Z. Note the eastward migration of the mobile ice pack, the solid look of the ice near Buffalo and the grounded ice in the western sub-basin.

\section{I972-73 IGE SEASON BREAK-UP}

Freeze-up began early in November 1972 (Assel, r974). Below-normal temperatures in the first half of January brought ice formation, but a thaw in late January and early February eased ice conditions. On 8 February, the wind shifted to the north-west as a cold front moved through the area, and the mean daily temperature dropped to $-5 \cdot 6^{\circ} \mathrm{C}$ at Detroit. Figure 6 (9 February 1973) shows older ice accumulating in the central basin with ice accumulating west of Long Point as well. New clear ice is probably forming all along the north shore.

On the next day's imagery (Fig. 7, Io February 1973) ice could be seen forming along the south shore, and the area of mobile pack ice in the center of the lake had enlarged noticeably. The winds in the eastern basin, however, were from the north setting up a wind shear over the central basin. These winds actually moved the pack to the west as they became northeasterly blowing out of a large high-pressure center moving to the north. The effect of three days of easterly winds is seen in the distribution of the lake ice on I $_{3}$ February (Fig. 8). Ice has been forced into the bay north of Long Point; the area between Long Point and the south shore from Buffalo to Erie is ice-free and the central basin continues to hold its mobile pack ice. The easterly winds persisted until I 5 February. On ${ }_{4}$ February the temperature rose above the freezing point, and on $\mathrm{I}_{5}$ February the wind again shifted to the north-west and the ice which by then totally covered Lake Erie was moved to the south. Evidence of this is seen on Figures 9 and ro ( 7 February 1973 was the coldest day of the month in Cleveland). Here the shape of the north shore line is preserved in the ice, the older, snow-covered, and more 


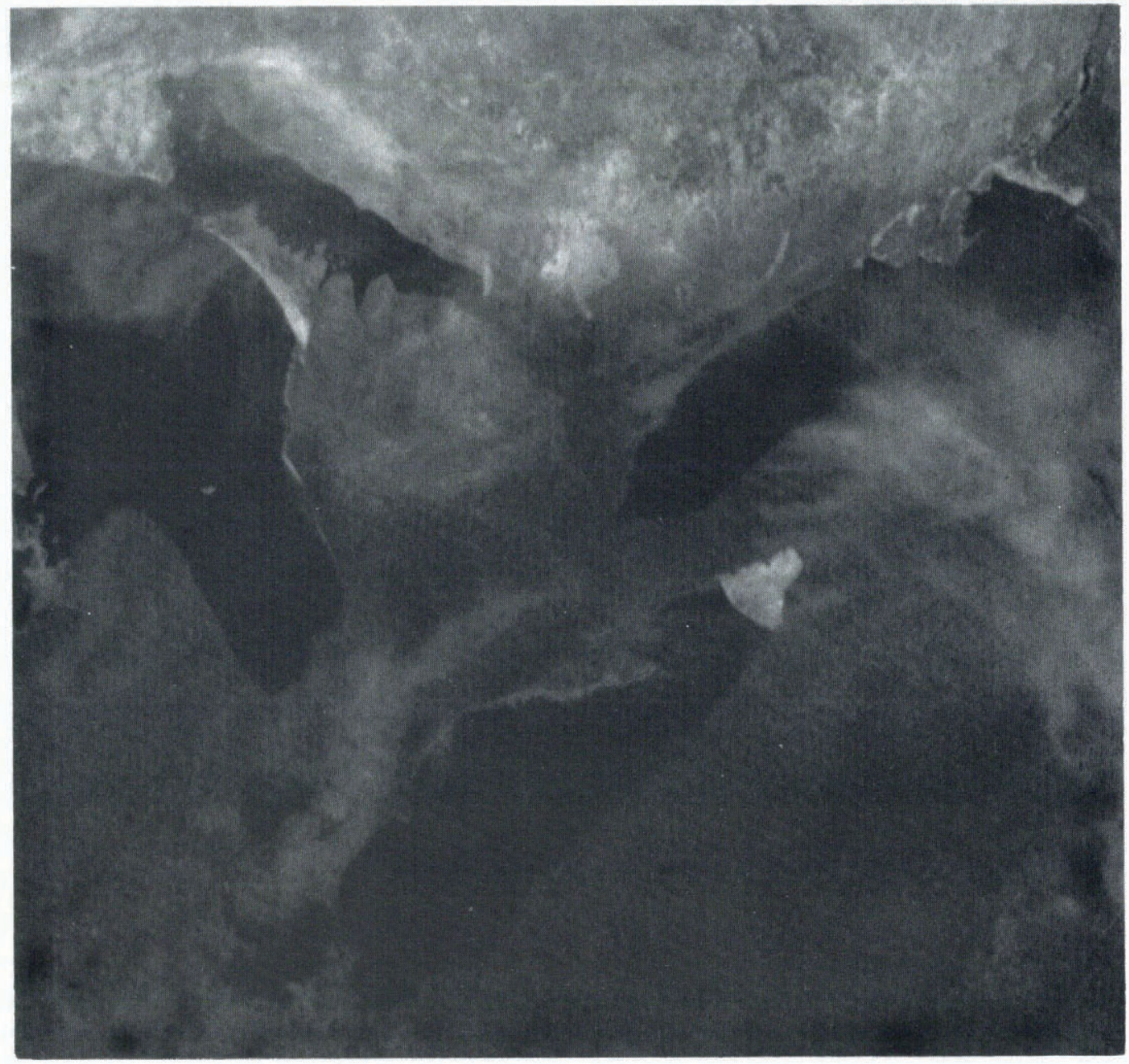

Fig. 5. NOAA-4 VHRR (visible), 24 March 1976, 15.00 Z. The only ice in Lake Erie is the "plug" at Buffalo. Note the straight, wind-formed edge of the rotting ice.

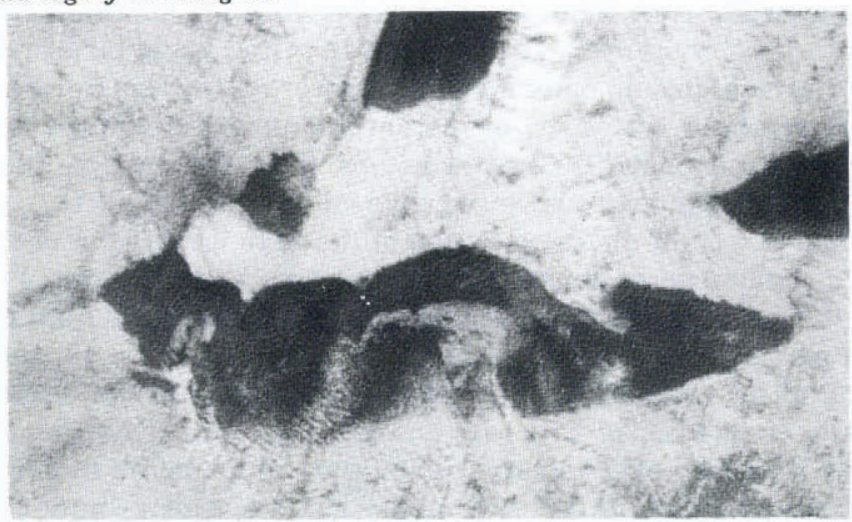

Fig. 6. NOAA-2 VHRR (visible), g February 1973, 15.00 Z. Older ice is accumulating in the central sub-basin. Clear new ice is probably forming all along the north shore and in the western sub-basin. 


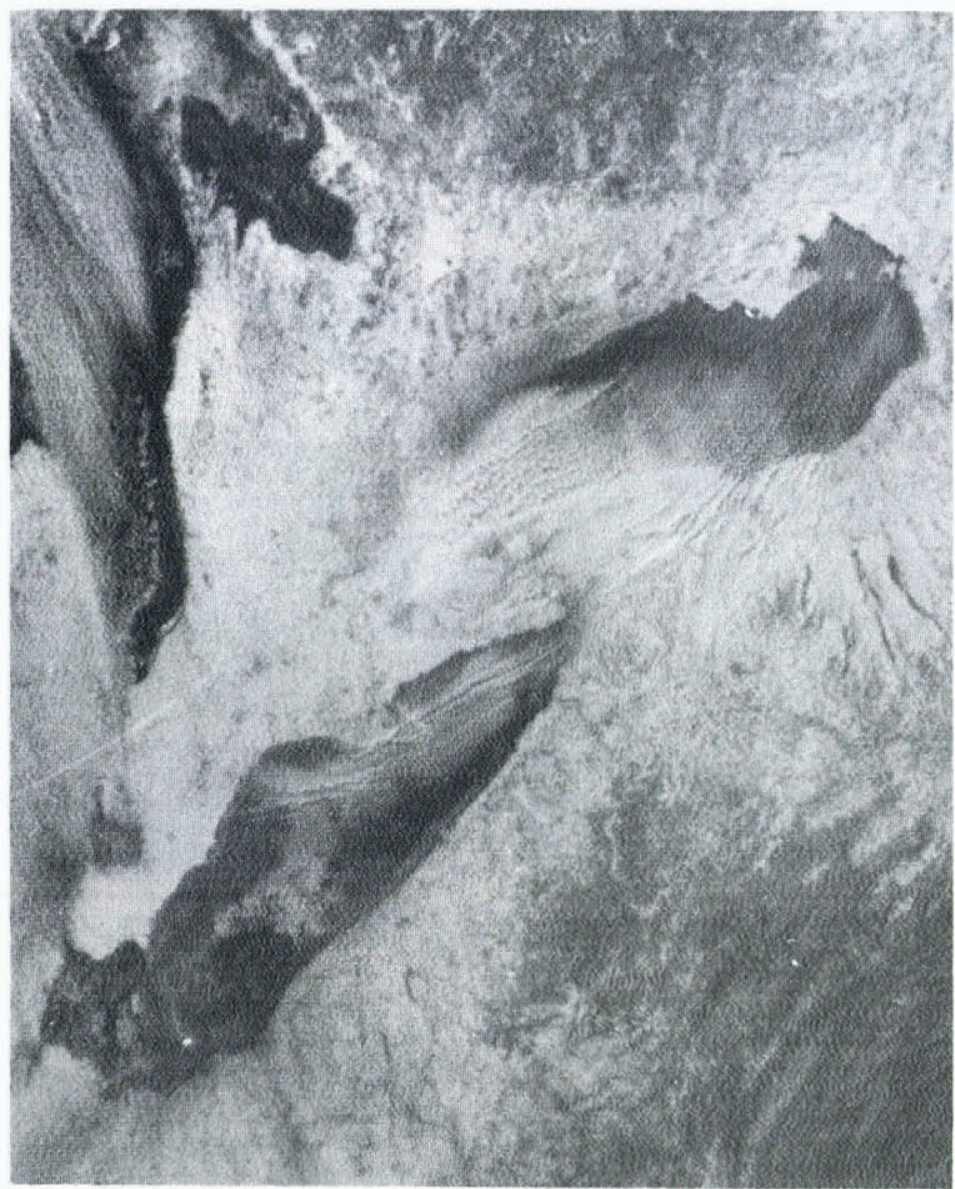

Fig. 7. NOAA-2 VHRR (visible), IO February 1973, 15.00 Z. Compare with Figure 6. Now ice is forming along all shores. The wind is south-westerly in Cleveland but north-easterly in Buffalo inhibiting eastward movement of the ice.

reflective ice has been forced against the south shore, and between Long Point and Erie, Pennsylvania, the ice from Long Point and along the Canadian shore has been moved south and east forming a thick ice dam across the narrowest part of the lake at the west edge of the eastern sub-basin. Reference to the bathymetric chart (Fig. I) shows how constricting this narrowing really is: a bottom ridge rises to within less than $15 \mathrm{~m}$ of the surface and extends to within $20 \mathrm{~km}$ of the south shore.

On 18 February a well-publicized satellite image of Lake Erie ice was taken by Landsat-I. Cloud-free conditions permitted a glimpse of the onset of break-up. Southerly winds at

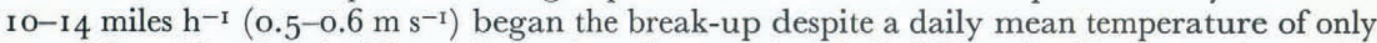
$-9.4^{\circ} \mathrm{C}$ at Cleveland. Three days of south-westerly winds followed. Figure I I shows the effect of the southerly wind. Tension cracks have opened up all along the south shore and along the islands that stretch across the lake. The ice is moving north and east.

On 23 February the lake was apparently ice-free in the area north of Long Point and the north-western part of the central sub-basin. During the $5 \mathrm{~d}$ cloud-covered period the winds had backed around through west to north-west. But temperatures continued to be below 


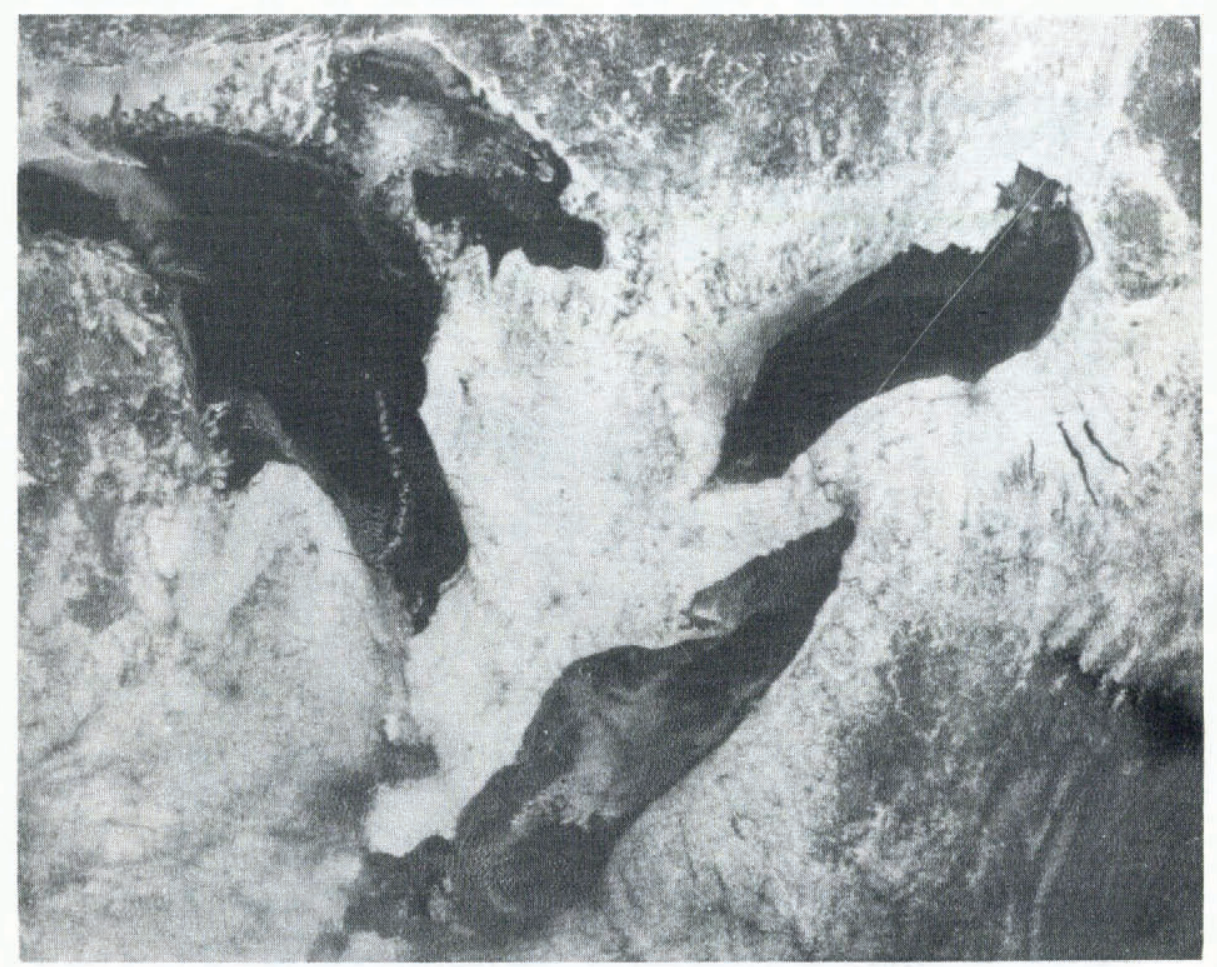

Fig. 8. NOAA-2 VHRR (visible), 13 February 1973, 15.00 Z. Compare with Figure 7. Note the ice in Long Point Bay. Note also the clear area south of Long Point. This pattern has resulted from the easterly winds of the previous three days.

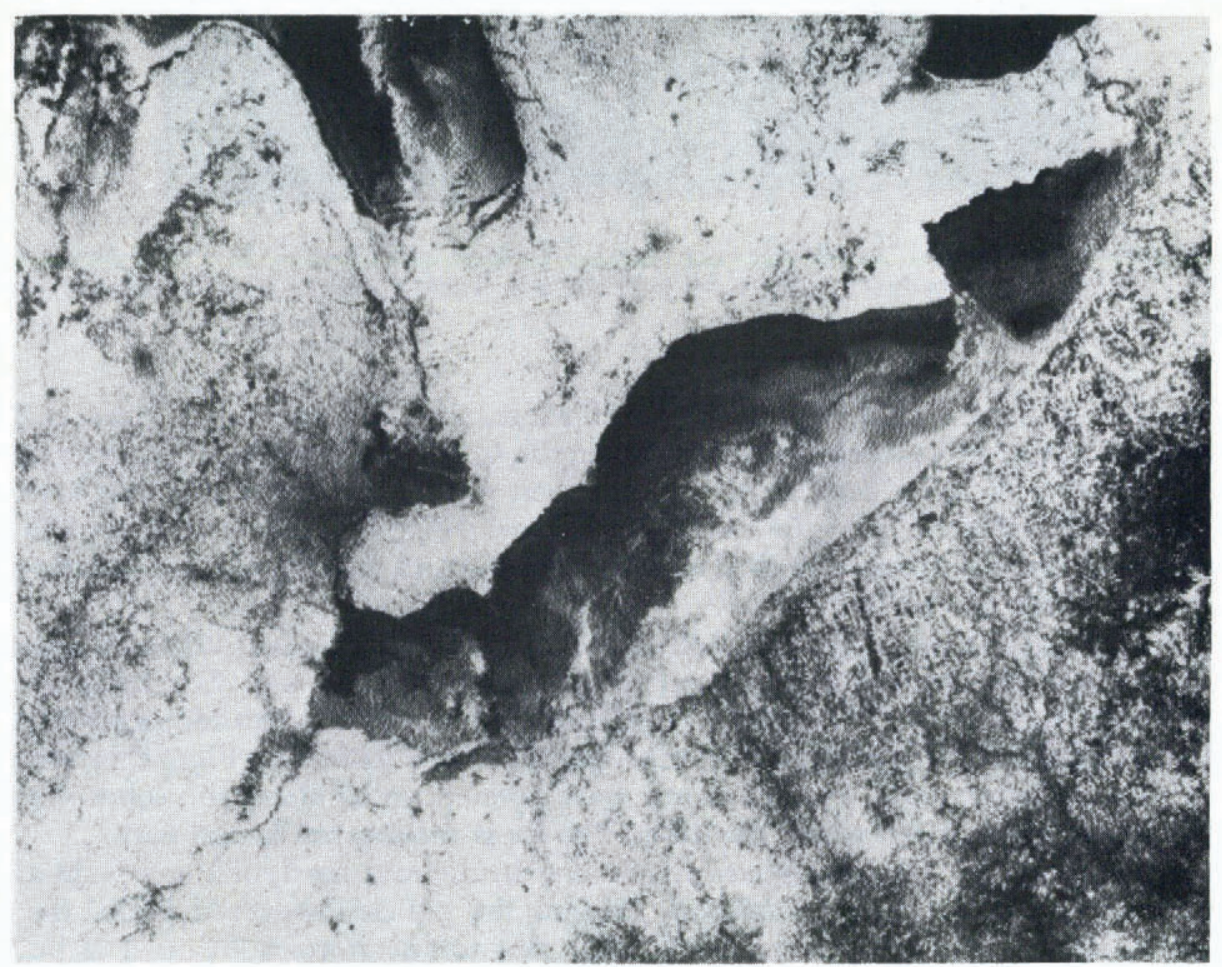

Fig. 9. NOAA-2 VHRR (visible), I7 February 1973, I5.00 Z. Computer-enhanced. Ice cover is nearly $100 \%$; the dark areas are newly-formed ice that is transparent, thin, and not snow-covered. Note the ice accumulation or "dam" at Long Point. 


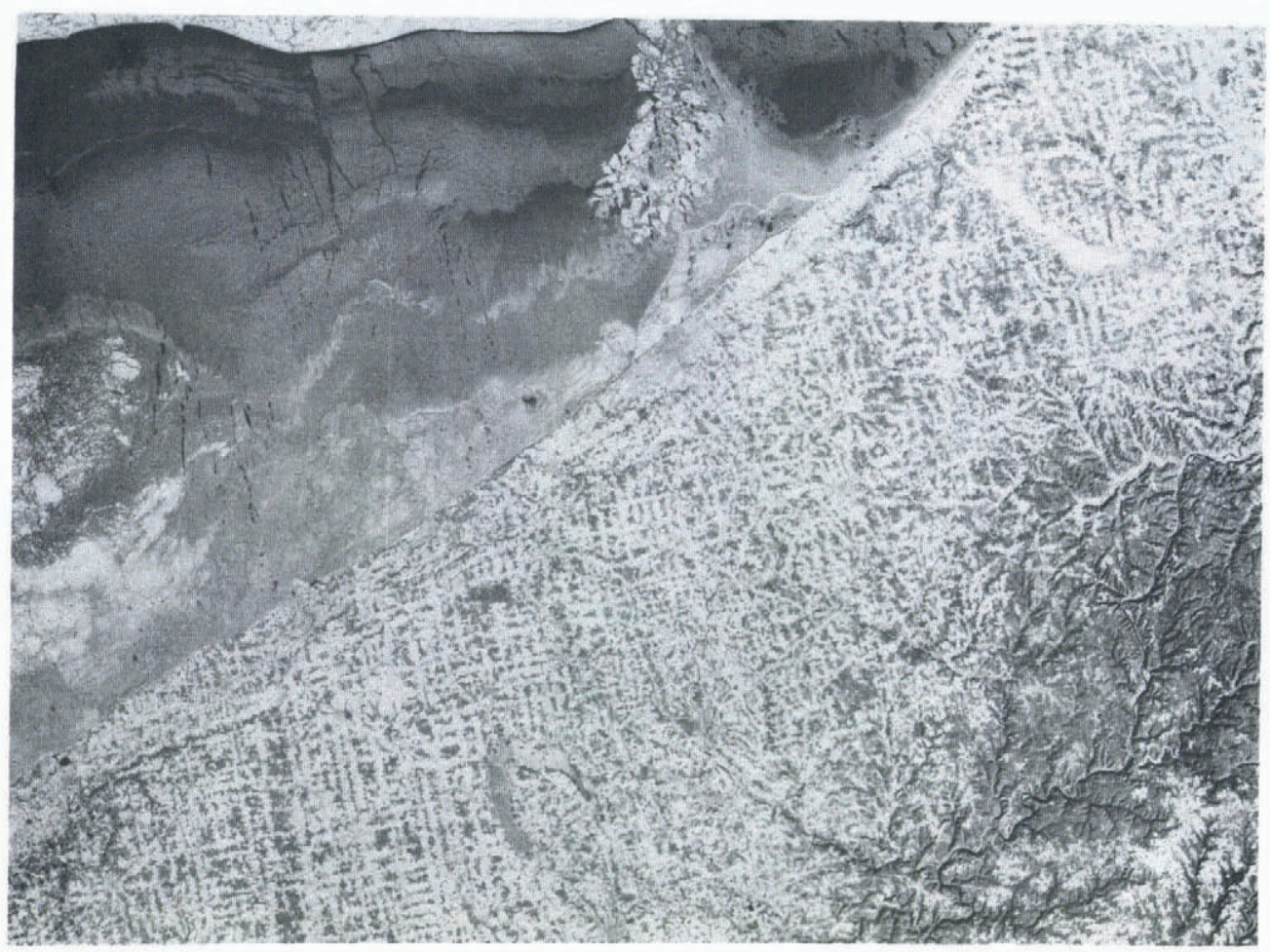

Fig. 10. Landsat-1 MSS-7, I7 February 1973, 16.30 Z. This image shows in exquisite detail the ice conditions on the lake.

freezing during this period, so new ice formed. On 24 February the north shore was all that was visible as the north-westerly winds blew off-shore, but the next day and for three days (Fig. 12) the winds were easterly; thus Buffalo and the north shore were ice-free.

By this time ice floes were large (10-30 km wide) and mobile. On 28 February, the lake ice was pushed farther to the west with the north-eastern shore of the central basin and the eastern half of the eastern basin ice-free.

A very warm strong southerly wind initiated widespread thawing as March began. The temperature did not fall below freezing again until I8 March. On 6 March it rose to a record $23.3^{\circ} \mathrm{C}$ at Cleveland. On 7 March the VHRR images show the ice piled up on the east-facing shores of the Canadian side of the lake and "rotten" and melting ice almost exclusively in the central sub-basin. On $8 \mathrm{March}$ (Fig. I3) another Landsat-I image revealed the same in more detail. Buffalo continued to be ice-free. Indeed the port of Buffalo opened without ice breaker assistance on $20 \mathrm{March}$, a full $22 \mathrm{~d}$ ahead of the average historical opening, and $25 \mathrm{~d}$ ahead of the forecasted opening. March water temperature for Lake Erie averaged a phenomenal $5.4 \mathrm{deg}$ above normal. None the less it was primarily the easterly wind that caused the early port opening at Buffalo, not the high temperature of the water.

\section{Concluding REMARKS}

Satellite observations of lake ice in the visible portion of the spectrum provide a useful method of monitoring ice formation and break-up. Over a period of years the empirical observations exhibit variations that can be analyzed in terms of meteorological, geomorphic, and thermal factors. This rudimentary study simply documents the results of a typical 


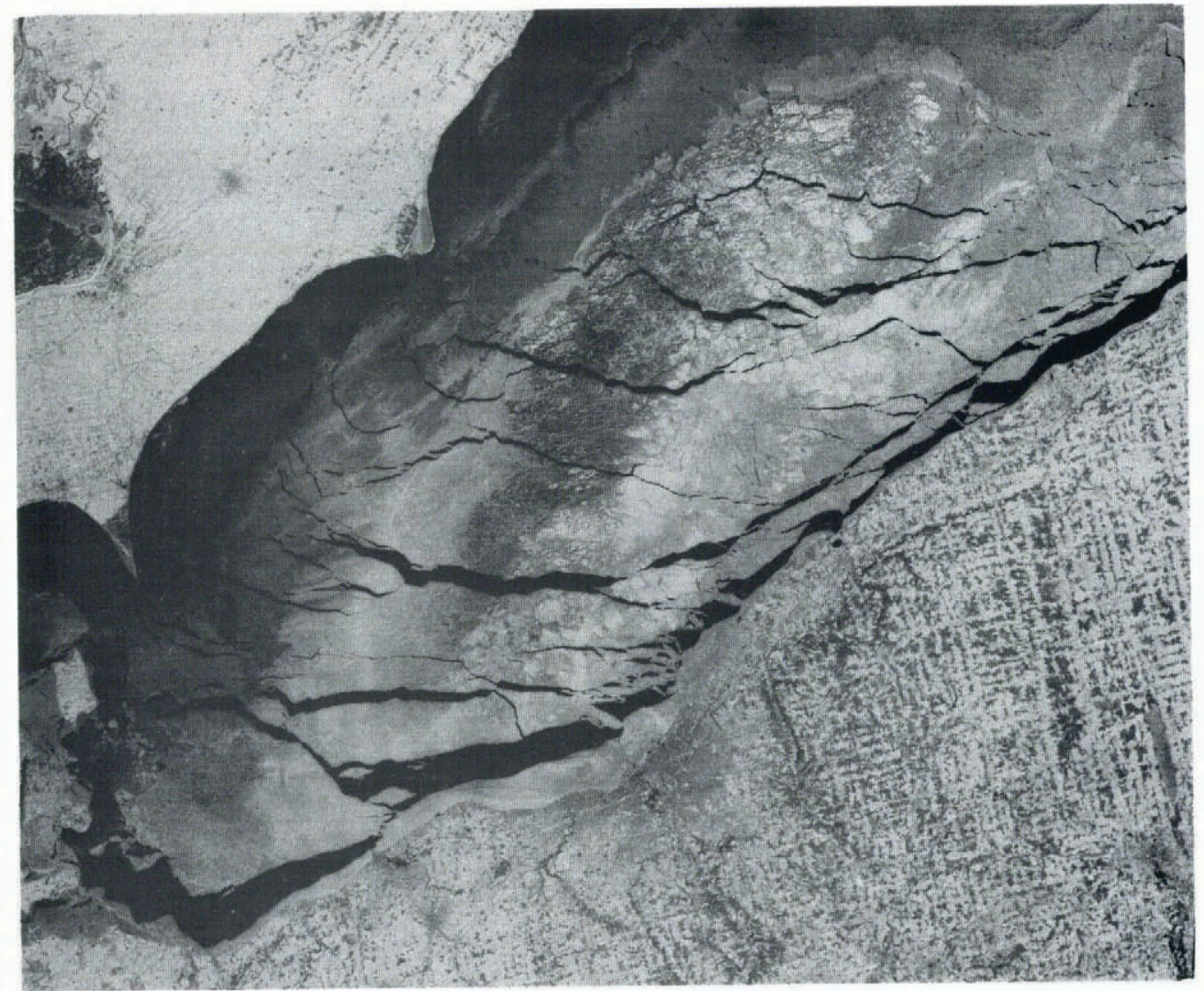

Fig. II. Landsat-I MSS-7, I8 February 1973, I6.30 Z. Southerly winds have shifted the ice to the north. Note the sharp angular breaks.

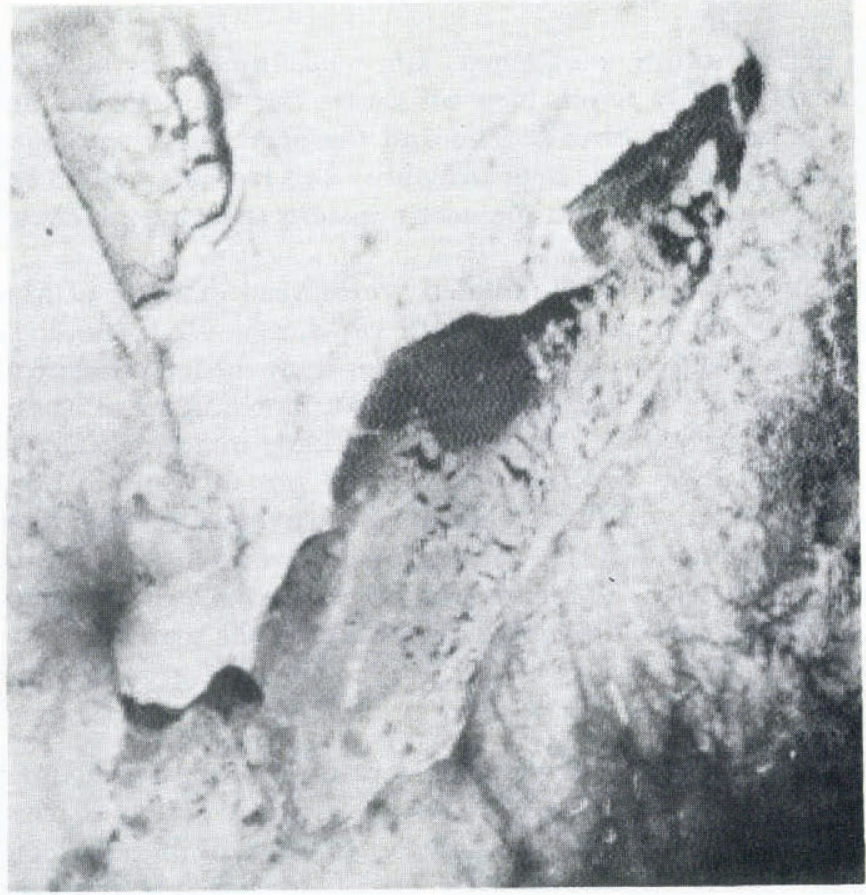

Fig. I2. NOAA-2 VHRR (visible), I March 1973, 15.0o Z. Easterly winds for three days have produced an anomalous break-up pattern. The ice has been blown to the west. Note the large floes. 


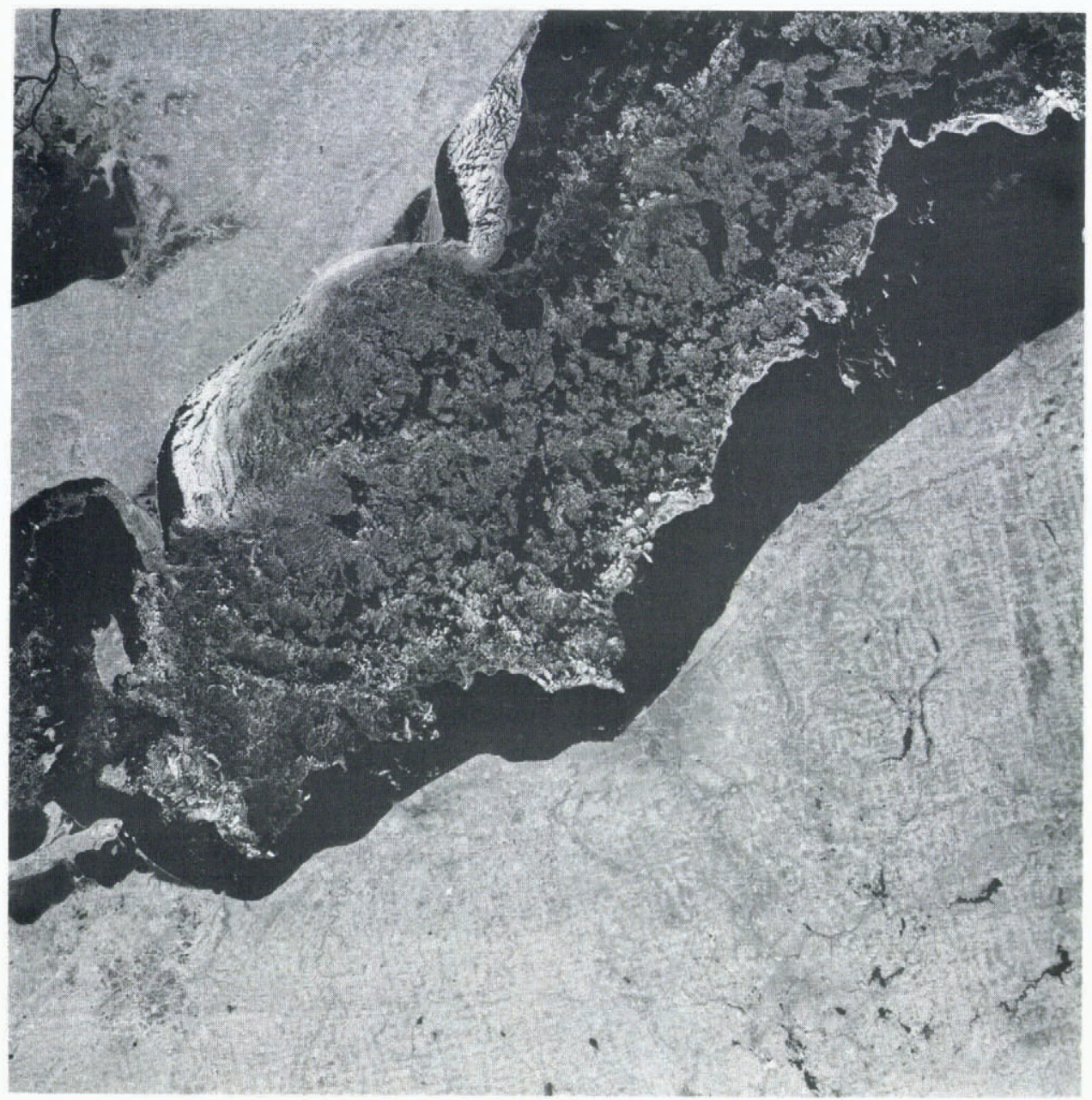

Fig. 13. Landsat-1 MSS-6, 8 March 1973, 16.30 Z. High temperatures and a southerly wind have reduced the pack to a rotten, lacy look. Note sastrugi and the low reflectance of the ice.

break-up as well as a very atypical one. Because of the satellite's continuing, repetitive coverage, not only can day-to-day changes be recorded but they can be compared to concomitant environmental changes.

In 1973, unseasonable easterly winds produced ice-free conditions in eastern Lake Erie $25 \mathrm{~d}$ earlier than forecast. In retrospect, the forecast could have been up-dated as early as I March to indicate an earlier-than-usual opening. In the author's view, the continuing accumulation of satellite data on lake ice will undoubtedly contribute significantly toward improved forecasting of ice break-up and formation. One additional satellite sensor needed is the day-night, all-weather capacity, such as side-looking airborne radar (SLAR) currently available only on aircraft, or the synthetic aperture radar (SAR) on Seasat-A. 


\section{Acknowledgements}

I would like to thank J. Wartha for allowing me to use the GOES images she collected, David G. Forsyth for preparing rectified and enhanced images, and Miss Annette Walker for her careful typing of the manuscript.

\section{REFERENCES}

Assel, R. A. 1974. Great Lakes ice cover, winter 1972-73. NOAA Technical Memorandum, NOS LSC D 7. Boyce, D. E. 1973. The r972-73 Great Lakes ice season. Mariners' Weather Log, Vol. i 7, No. 5, p. $285-88$.

Hartley, R. P. 1968. Bottom currents in Lake Erie. (In International Association for Great Lakes Research. Proceedings, eleventh Conference on Great Lakes Research held at the University of Wisconsin-Milwaukee, Wisconsin, April 18-20, 1968. Ann Arbor, Mich. [printed], International Association for Great Lakes Research, p. 398-405.)

Hutchinson, G. E. [ ${ }^{\mathrm{c}}$ I957.] A treatise on limnology. Vol. 1 . New York, John Wiley and Sons, Inc.

Irbe, J. G. I 969 . Some unusual surface water temperature patterns in the Great Lakes, as detected by airborne radiation thermometer surveys. (In International Association for Great Lakes Research. Proceedings, twelfth Conference on Great Lakes Research held at the University of Michigan, Ann Arbor, Michigan, May 5-7, 1969. Ann Arbor, Mich. [printed], International Association for Great Lakes Research, p. 583-607.)

Leshkevich, G. A. 1976. Great Lakes ice cover, winter 1974-75. NOAA Technical Report, ERL 370-GLERL I I. (GLERL Contribution No. 78.)

McMillan, M. C., and Forsyth, D. G. 1976. Satellite images of Lake Erie ice: January-March 1975 . NOAA Technical Memorandum, NESS 8o.

Stewart, K. M. 1973. Winter conditions in Lake Erie with reference to ice and thermal structure and comparison to Lakes Winnebago (Wisconsin) and Mille Lacs (Minnesota). (In International Association for Great Lakes Research. Proceedings, sixteenth Conference on Great Lakes Research. Hosted by the Ohio State University and held at Sawmill Creek Hotel, Huron, Ohio, ${ }_{1} 6-18$ April, 1973. Ann Arbor, Mich. [printed], International Association for Great Lakes Research, p. 845-57.)

Strong, A. E. 1973. New sensor on NOAA-2 satellite monitors the 1972-73 Great Lakes ice season. (In Thomson, K. P. B., and others, ed. Remote sensing and water resources management. Edited by $K$. P. B. Thomson, R. K. Lane, S. C. Csallany. Urbana, Illinois, American Water Resources Association, p. I 7 I -78 . (Proceedings, No. 17.))

Wartha, J. H. 1977. Lake Erie ice: winter 1975-76. NOAA Technical Memorandum, NESS 90.

Wiesnet, D. R., and McGinnis, D. F. 1973. Hydrologic applications of the NOAA-2 very high resolution radiometer. (In Thomson, K. P. B., and others, ed. Remote sensing and water resources management. Edited by $K$. P. B. Thomson, R. K. Lane, S. C. Csallany. Urbana, Illinois, American Water Resources Association, p. 179-9o. (Proceedings, No. 17.)) 